\title{
Erratum: Neuronal Effects of Listening to Entrainment Music Versus Preferred Music in Patients With Chronic Cancer Pain as Measured via EEG and LORETA Imaging
}

\author{
Frontiers Production Office* \\ Frontiers Media SA, Lausanne, Switzerland
}

Keywords: music therapy, EEG, LORETA (Low Resolution Electromagnetic Tomography), case study, chronic pain, cancer, pain

Frontiers Editorial Office,

Frontiers Media SA, Switzerland

*Correspondence:

Frontiers Production Office

production.office@frontiersin.org

Specialty section:

This article was submitted to Psychology for Clinical Settings,

a section of the journal

Frontiers in Psychology

Received: 31 January 2022

Accepted: 31 January 2022

Published: 22 February 2022

Citation:

Frontiers Production Office (2022)

Erratum: Neuronal Effects of Listening

to Entrainment Music Versus Preferred

Music in Patients With Chronic Cancer

Pain as Measured via EEG and

LORETA Imaging.

Front. Psychol. 13:866996.

doi: 10.3389/fpsyg.2022.866996

\section{An Erratum on}

Neuronal Effects of Listening to Entrainment Music Versus Preferred Music in Patients With Chronic Cancer Pain as Measured via EEG and LORETA Imaging

by Hunt, A. M., Fachner, J., Clark-Vetri, R., Raffa, R. B., Rupnow-Kidd, C., Maidhof, C., and Dileo, C. (2021). Front. Psychol. 12:588788. doi: 10.3389/fpsyg.2021.588788

Due to a production error, a reference was wrongly included in the reference list and incorporated an incorrect DOI. The reference "Dileo, C., Hunt, A., Vetri, R., Raffa, R. B., and Rupnow-Kidd. (2021). Effects of music therapy entrainment on pain, vital signs, and bowel function of cancer patients. Complement. Ther. Med.23, 714-718. doi: 10.1016/j.ctim.2015.08.002” should be removed from the reference list, and the in-text citation "Dileo et al., 2021" should instead be written as "Dileo et al., in preparation."

The publisher apologizes for this mistake. The original article has been updated.

Copyright $\odot 2022$ Frontiers Production Office. This is an open-access article distributed under the terms of the Creative Commons Attribution License (CC BY). The use, distribution or reproduction in other forums is permitted, provided the original author(s) and the copyright owner(s) are credited and that the original publication in this journal is cited, in accordance with accepted academic practice. No use, distribution or reproduction is permitted which does not comply with these terms. 